\title{
Expansion of the geographical distribution of the Caribbean reef octopus (Octopus briareus) to the Gulf of Mexico
}

\section{Expansión de la distribución geográfica del pulpo de arrecife caribeño (Octopus briareus) hacia el golfo de México}

Marco Antonio Ponce-Márquez ${ }^{1}$, Miguel Ángel Gamboa-Álvarez ${ }^{2,3 *}$, Julio Enrique De la Rosa-Castillo ${ }^{4}$, Jorge Alberto López-Rocha ${ }^{1,5}$, Carlos Rosas ${ }^{1}$

${ }^{1}$ Unidad Multidisciplinaria de Docencia e Investigación, Facultad de Ciencias, Universidad Nacional

Autónoma de México, CP 97130, Sisal, Yucatán, Mexico.

2 Posgrado Institucional en Ciencias Agropecuarias y Manejo de Recursos Naturales Tropicales, Campus de Ciencias Biológicas y Agropecuarias-Facultad de Medicina Veterinaria y Zootecnia, Universidad Autónoma de Yucatán, CP 97315, Mérida, Yucatán, Mexico.

${ }^{3}$ Unidad de Vida Silvestre y Medio Ambiente, A. C., CP 97315, Sierra Papacal, Yucatán, Mexico.

${ }^{4}$ Instituto Tecnológico de Conkal, km 16.3, Antigua Carretera Mérida-Motul, CP 97345 Conkal, Yucatán, Mexico.

${ }^{5}$ Laboratorio de Análisis Espacial de Zonas Costeras, Sierra Papacal, CP 97315, Yucatán, Mexico.

* Corresponding author. E-mail: miguel_gambo@hotmail.com

\begin{abstract}
An Octopus briareus specimen was recorded off Port Sisal, Yucatán, Mexico. This finding represents the first record of O. briareus in the southern Gulf of Mexico, expanding the currently known westernmost distribution area for this species on the American continent. The specimen was captured by scientific divers performing routine maintenance at underwater facilities in the area of the discovery. The collected specimen was an adult female weighing $25.3 \mathrm{~g}$. The presence of $O$. briareus could be related to changes in the environmental conditions in the Caribbean Sea and the Gulf of Mexico.
\end{abstract}

Key words: Octopus briareus, Gulf of Mexico, expansion, distribution.

RESUMEN. Se registró un espécimen de Octopus briareus frente al puerto de Sisal, Yucatán, México. Este hallazgo representa el primer registro de $O$. briareus en aguas del sur del golfo de México, lo cual expande el área de distribución más occidental actualmente reconocida para esta especie en el continente americano. El espécimen fue capturado por buzos científicos que realizaban tareas de mantenimiento de rutina en instalaciones submarinas en el área del descubrimiento. El espécimen recolectado fue una hembra adulta que pesaba $25.3 \mathrm{~g}$. La presencia de O. briareus podría estar relacionada con cambios en las condiciones ambientales del mar Caribe y el golfo de México.

Palabras clave: Octopus briareus, golfo de México, expansión, distribución.

\section{INTRODUCTION}

British zoologist Guy Colborn Robson described the Caribbean reef octopus, Octopus briareus, in 1929 (Robson 1929a). Like other cephalopods, this species is capable of changing its color to instantly mimic its surroundings, although its natural coloration is speculated to be a combination of colors between blue and green with brown spots (Snyderman and Wiseman 1996). The species has large prominent eyes, usually surrounded by very dark rings, and very long arms equivalent in length to 5 times that of the mantle (Kaplan 1999). Males and females are similar in appearance, but males have a modified arm (hectocotylus) that is essential for reproduction (Hanlon and Messenger 1996).

Current knowledge concerning the biological and ecological aspects of $O$. briareus is very limited, but the spatial distribution of this species is known to extend from southern

\section{INTRODUCCIÓN}

El zoólogo británico Guy Colborn Robson describió al pulpo del arrecife caribeño, Octopus briareus, en 1929 (Robson 1929a). Al igual que otros cefalópodos, esta especie es capaz de cambiar su color para imitar instantáneamente su entorno, aunque se especula que su coloración natural es una combinación de colores entre azul y verde con manchas marrones (Snyderman y Wiseman 1996). La especie tiene ojos grandes y prominentes, generalmente rodeados de anillos muy oscuros, y brazos muy largos equivalentes en longitud a 5 veces la del manto (Kaplan 1999). Los machos y las hembras son similares en apariencia, pero los machos tienen un brazo modificado (hectocótilo) que es esencial para la reproducción (Hanlon y Messenger 1996).

El conocimiento actual sobre los aspectos biológicos y ecológicos de $O$. briareus es muy limitado, pero se reconoce que la distribución espacial de esta especie se extiende 
Florida (USA) and the West Indies (Central America) to the northern coast of South America (Aronson 1986, Cervigón et al. 1992, Jereb et al. 2014, Kaschner et al. 2019) (Fig. 1). It has been suggested that the $O$. briareus distribution range could include the southern Gulf of Mexico (Robson 1929b, Pickford 1945, Hanlon 1983, Voss et al. 1998), but there is no formal record of the presence of this species there to date.

Since the early 2000s, the Caribbean Basin and the Atlantic Ocean (typical distribution areas for O. briareus) have shown increasing trends in sea surface temperature (SST) (Nurse and Charlery 2016). Sheppard and Rioja-Nieto (2005) estimated an upward trend in SST for the Caribbean that is consistent with global trends. Jury (2011) described a positive trend for SST off the Antilles, suggesting accelerated warming in recent years, and Lluch-Cota et al. (2013) reported an average increasing trend in the range of $0.05-0.27{ }^{\circ} \mathrm{C}$ per decade for SST in the southeastern Gulf of Mexico and the western Caribbean Sea. Warming trends are likely to affect marine organisms in different ways (migration, gametogenesis, spawning) (Chollett et al. 2012). Changes in the phenology and distribution of marine species, including cephalopods, in response to recent changes in temperature have already been reported in different parts of the world (Philippart et al. 2003, Weishampel et al. 2004, Poloczanska et al. 2016).

Here, we describe the first record of a female Caribbean reef octopus, O. briareus, in the southern Gulf of Mexico (Yucatán Peninsula), formally expanding the species' known distribution on the American continent. We also discuss the possible cause of the movement of the species.

\section{MATERIALS AND METHODS}

\section{Study area}

The Gulf of Mexico (Fig. 1) is a small, semiclosed ocean basin with tropical marine currents that occupies 1.5 million square kilometers (Bryant et al. 1991, Salvador 1991). It is part of the circulation of the Atlantic Ocean channeling the transport of heat, salt, nutrients, and biological material from the Caribbean Sea to the North Atlantic. It also plays an important role in defining the weather and climate of Central America, the United States of America, and the Caribbean Sea (Muller-Karger et al. 2015). Clear and warm surface waters from the Caribbean Sea enter the basin via the Yucatán Current, forming the Loop Current and the rings that derive from it (Candela et al. 2003, Schmitz et al. 2005, Smith et al. 2014). Six bodies of water have been detected in the Gulf of Mexico, four of external origin, stemming from the inherent relationship with the Atlantic Ocean and introduced into the Gulf of Mexico by the Yucatán-Lazo current system (Vidal et al. 1991), and two known as the $18{ }^{\circ} \mathrm{C}$ water mass, detected in the northern subtropical region of the Gulf desde el sur de Florida (EUA) y las Indias Occidentales (Centroamérica insular) hasta la costa norte de América del Sur (Aronson 1986, Cervigón et al. 1992, Jereb et al. 2014, Kaschner et al. 2019) (Fig. 1). Se ha sugerido que la distribución de $O$. briareus podría incluir el sur del golfo de México (Robson 1929b, Pickford 1945, Hanlon 1983, Voss et al. 1998), pero hasta la fecha no ha habido un registro formal de la presencia de esta especie ahí.

Desde la década de 2000, la cuenca del Caribe y el océano Atlántico (áreas de distribución habituales de O. briareus) han mostrado tendencias crecientes en la temperatura de la superficie del mar (TSM) (Nurse y Charlery 2016). Sheppard y Rioja-Nieto (2005) estimaron una tendencia al alza en la TSM para el Caribe que es consistente con las tendencias mundiales. Jury (2011) describió una tendencia positiva para la TSM frente a las Antillas, y sugirió una aceleración del calentamiento en los últimos años, mientras que Lluch-Cota et al. (2013) reportaron una tendencia promedio de aumento de la TSM en el intervalo de $0.05-0.27{ }^{\circ} \mathrm{C}$ por década para el sureste del golfo de México y el mar Caribe occidental. Es probable que las tendencias de calentamiento afecten a los organismos marinos de diferentes maneras (migración, gametogénesis, desove) (Chollett 2012). Ya se han informado cambios en la fenología y la distribución de especies marinas, incluidos los cefalópodos, en respuesta a los cambios recientes en la temperatura en diferentes partes del mundo (Philippart et al. 2003, Weishampel et al. 2004, Poloczanska et al. 2016).

En este trabajo, describimos el primer registro de una hembra de pulpo de arrecife del Caribe, O. briareus, en las aguas del sur del golfo de México (península de Yucatán) $\mathrm{y}$, de esta manera, formalmente expandimos la distribución reconocida de la especie en el continente americano. También discutimos la posible causa del desplazamiento de la especie.

\section{MATERIALES Y MÉTODOS}

\section{Área de estudio}

El golfo de México (Fig. 1) es una pequeña cuenca oceánica semicerrada con corrientes marinas tropicales que ocupa un área de 1.5 millones de kilómetros cuadrados (Bryant et al. 1991, Salvador 1991). Es parte de la circulación del océano Atlántico que canaliza el transporte de calor, sal, nutrientes y material biológico, desde el mar Caribe hasta el Atlántico Norte. Además, juega un papel importante en la definición del tiempo y el clima de Centroamérica, los Estados Unidos de América y el mar Caribe (Muller-Karger et al. 2015). Aguas claras y cálidas de la superficie del mar Caribe ingresan a la cuenca a través de la corriente de Yucatán, para formar la corriente del Lazo y los anillos derivados de ella (Candela et al. 2003, Schmitz et al. 2005, Smith et al. 2014). Se han detectado 6 cuerpos de agua en el golfo de México, cuatro de origen externo, originados de la relación inherente con el océano Atlántico e introducidos en el golfo de México por el sistema de corriente de Lazo de Yucatán (Vidal et al. 1991), y 
of Mexico, and the common gulf water, detected throughout practically the entire gulf.

\section{Specimen collection}

The $O$. briareus specimen was collected on 8 August, 2019, at 12:20 PM, in a location $14 \mathrm{~km}$ out from Port Sisal, Yucatán, Mexico $\left(21^{\circ} 13.263^{\prime} \mathrm{N}, 90^{\circ} 10.045^{\prime} \mathrm{W}\right.$ ) (Fig. 1). The discovery was made by scientific divers performing routine work at underwater facilities located in the area. Following its collection, the organism was transferred alive to the cephalopod culture laboratory in the Unidad Multidisciplinaria de Docencia e Investigación at the Universidad Nacional Autónoma de México, at Sisal, in a thermal container with $20 \mathrm{~L}$ of seawater. Since there was no oxygenation equipment, and to avoid stressing the animal, the seawater in the container was changed twice during the trip. The octopus was identified following the method proposed by Robson (1929b). The trip to the laboratory was made in a $14-\mathrm{m}$ long boat with two 115 -hp outboard motors; approximate trip time is 28 min under optimal navigation conditions.

\section{ReSULTS}

An O. briareus specimen was collected off Port Sisal, Yucatán, Mexico. The organism was an adult female with the following morphometrics: weight $=25.3 \mathrm{~g}$, total length $=$ $20.8 \mathrm{~cm}$, mantle length $=3.7 \mathrm{~cm}$, length of longest arm $=$ $17.1 \mathrm{~cm}$, and eye circumference $=2.1 \mathrm{~cm}$ (Fig. 2). The discovery was made in an area with depth down to $9.7 \mathrm{~m}$, temperature of $24.0{ }^{\circ} \mathrm{C}$ and visibility up to $12.0 \mathrm{~m}$; the ocean dos conocidos como la masa de agua a $18{ }^{\circ} \mathrm{C}$, detectada en la región subtropical norte del golfo de México, y el agua común del golfo, detectada en prácticamente todo el golfo.

\section{Recolecta del ejemplar}

El espécimen de $O$. briareus se recolectó el 8 de agosto de 2019 a las 12:20 PM en una ubicación a $14 \mathrm{~km}$ del puerto de Sisal, Yucatán, México. $\left(21^{\circ} 13.263^{\prime} \mathrm{N}, 90^{\circ} 10.045^{\prime} \mathrm{W}\right)$ (Fig. 1). El descubrimiento fue realizado por buzos científicos que realizaban trabajos de rutina en instalaciones submarinas ubicadas en el área. Después de su recolección, el organismo fue transferido vivo al laboratorio de cultivo de cefalópodos de la Unidad Multidisciplinaria de Docencia e Investigación de la Universidad Nacional Autónoma de México, con sede en Sisal, en un recipiente térmico que contenía $20 \mathrm{~L}$ de agua de mar. Debido a la falta de equipos de oxigenación, y para evitar estresar al animal, el agua de mar en el contenedor se cambió 2 veces durante el viaje. El pulpo se identificó mediante el método propuesto por Robson (1929b). El viaje al laboratorio se realizó en un bote de $14 \mathrm{~m}$ de largo con 2 motores fueraborda de $115 \mathrm{hp}$; el tiempo estimado para el viaje en cuestión es de 28 min en condiciones óptimas de navegación.

\section{Resultados}

Se recolectó un espécimen de $O$. briareus frente al puerto de Sisal, Yucatán, México. El organismo era una hembra adulta con los siguientes datos morfométricos: peso $=$ $25.3 \mathrm{~g}$, longitud total $=20.8 \mathrm{~cm}$, longitud del manto $=3.7 \mathrm{~cm}$, longitud del brazo más largo $=17.1 \mathrm{~cm}$ y circunferencia del ojo $=2.1 \mathrm{~cm}$ (Fig. 2). El descubrimiento se realizó en un área

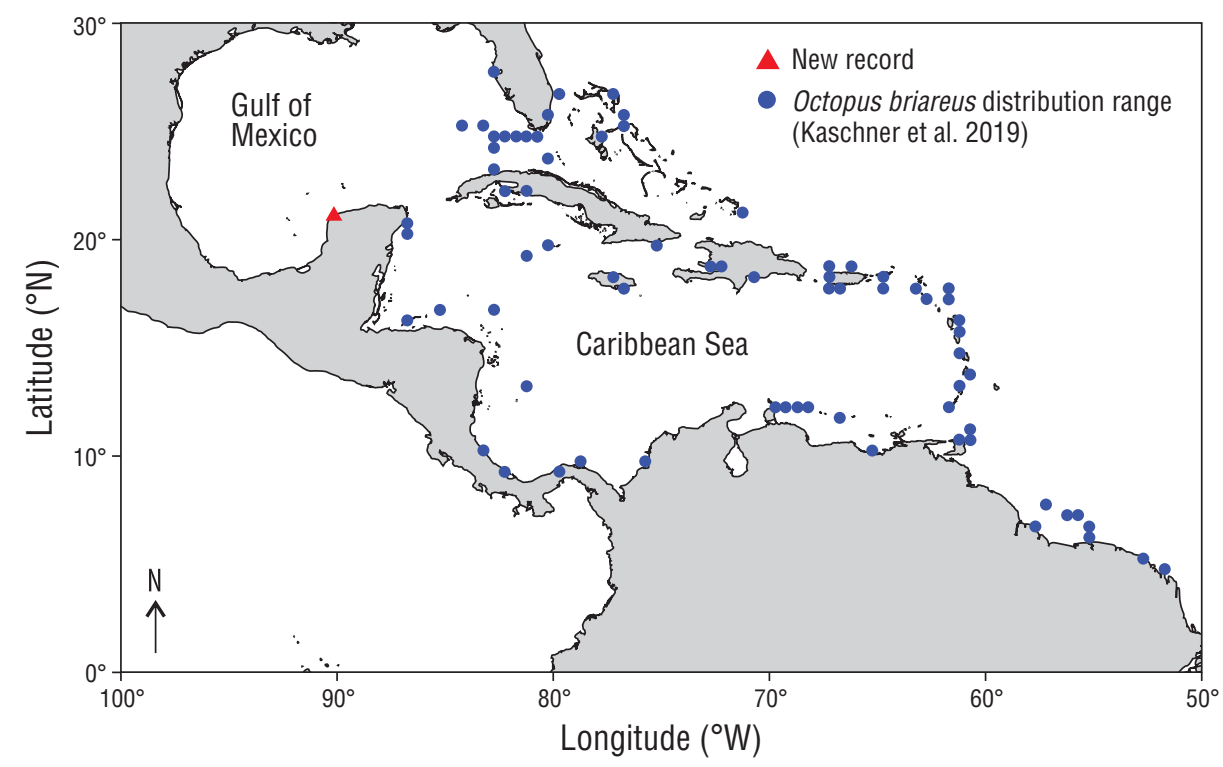

Figure 1. Octopus briareus distribution (Kaschner et al. 2019) along the Caribbean Sea and the northern coast of South America and location of the new recording off Port Sisal, Yucatan, Mexico.

Figura 1. Distribución de Octopus briareus (Kaschner et al. 2019) a lo largo del mar Caribe y la costa norte de América del Sur y la ubicación del nuevo sitio de registro frente al puerto de Sisal, Yucatán, México. 

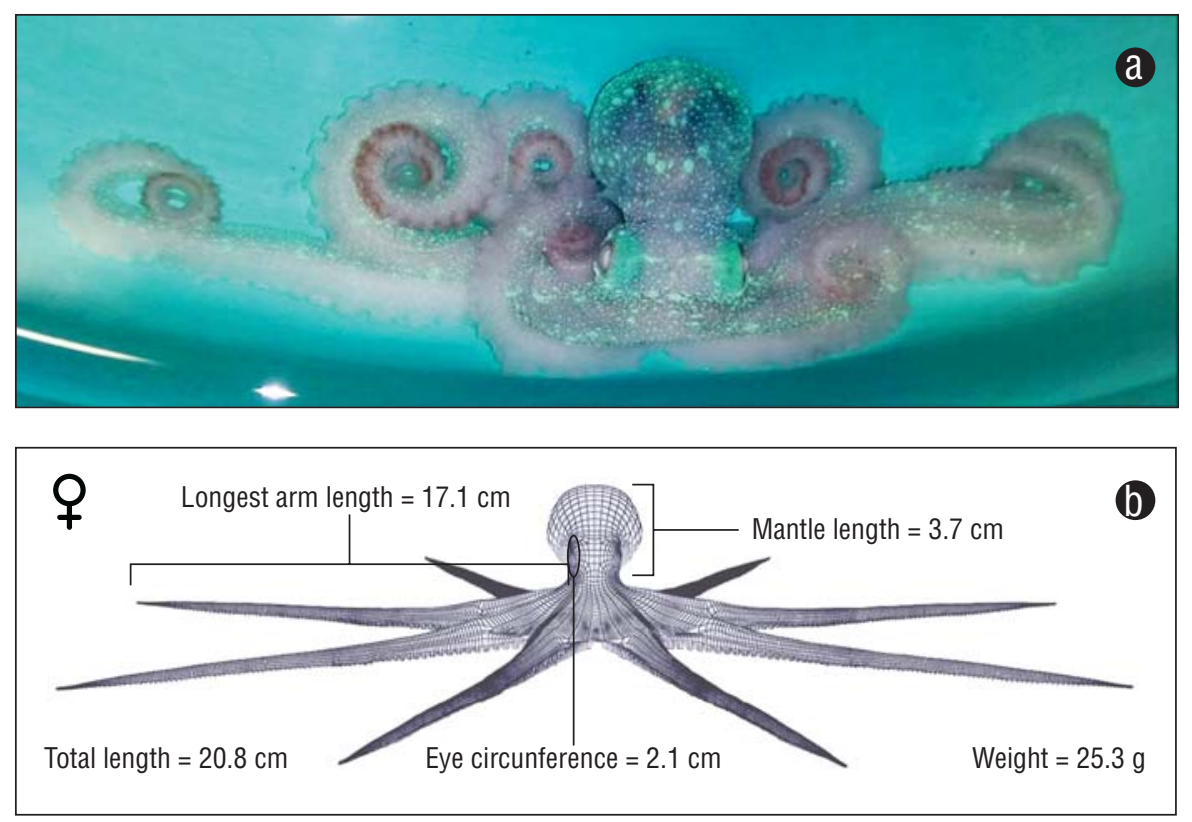

Figure 2. (a) Photograph of the Octopus briareus (Robson 1929) specimen captured off Port Sisal, Yucatan, Mexico. (b) Three-dimensional representation and main morphometric characters of the captured specimen.

Figura 2. (a) Fotografía del espécimen de Octopus briareus (Robson 1929) capturado frente al puerto de Sisal, Yucatán, México. (b) Representación tridimensional y principales caracteres morfométricos del espécimen capturado.

floor in this location was mainly composed of brown algae and medium sand.

\section{Discussion}

The discovery of this $O$. briareus specimen is interesting because it suggests that the species could be expanding its westernmost distribution range to areas in the Gulf of Mexico. We could put forward 2 hypotheses. The first is that given the tolerance of $O$. briareus embryos to high temperatures (unpublished data) and the climatic changes that have occurred in the area, the species has expanded its distribution because environmental conditions have been favorable. This distribution expansion may have been induced by SST anomalies in the Caribbean, which have been of greater intensity in recent years (Foltz et al. 2018, Varela et al. 2018, Jury 2019). The geographical expansion of various cephalopod species around the world has been documented, with changes in SST being suggested as possible causes (Table 1). Increased SST is also known to be related to coral bleaching and ocean acidification (Nurse and Charlery 2016), and these phenomena could cause massive habitat loss for this and other species. Allcock and Headlam (2018) suggested that even with its wide distribution range, $O$. briareus could be at risk given the long-term future theoretical threat from global warming. This species, like many other cephalopods, is very sensitive to environmental changes and is thus considered a good indicator of the present oceanographic conditions (Puerta et al. 2015, Zaragoza et al. 2015). The second hypothesis is that the species has always inhabited the area, but given its low con profundidad de $9.7 \mathrm{~m}$, temperatura de $24.0{ }^{\circ} \mathrm{C}$ y visibilidad de hasta $12.0 \mathrm{~m}$; el fondo del océano en este lugar estaba compuesto principalmente de algas pardas y arena de grano medio.

\section{Discusión}

El descubrimiento de este espécimen de $O$. briareus es interesante, ya que sugiere que la especie podría estar expandiendo su rango de distribución más occidental a áreas del golfo de México. Podríamos proponer 2 hipótesis. La primera es que debido a la tolerancia de los embriones de O. briareus a las altas temperaturas (datos no publicados) y a los cambios climáticos que se han producido en el área, la especie ha ampliado su distribución porque las condiciones ambientales le han sido favorables. Esta expansión de distribución pudo haber sido inducida por anomalías de la TSM en el Caribe, que se han presentado con mayor intensidad en los últimos años (Foltz et al. 2018, Varela et al. 2018, Jury 2019). Se ha documentado la expansión geográfica de varias especies de cefalópodos en todo el mundo, y los cambios en la TSM han sido sugeridos como posibles causas (Tabla 1). También se sabe que el aumento de la TSM está relacionado con el blanqueamiento de los corales y la acidificación de los océanos (Nurse y Charlery 2016), fenómenos que podrían causar la pérdida masiva de hábitats de esta y otras especies. Allcock y Headlam (2018) sugieren que incluso con su amplia distribución, $O$. briareus podría estar en riesgo dado que existe una amenaza teórica futura a largo plazo por el calentamiento global. Esta especie, como muchos otros cefalópodos, es muy 
Ponce-Márquez et al.: Expansion of the geographical distribution of Octopus briareus

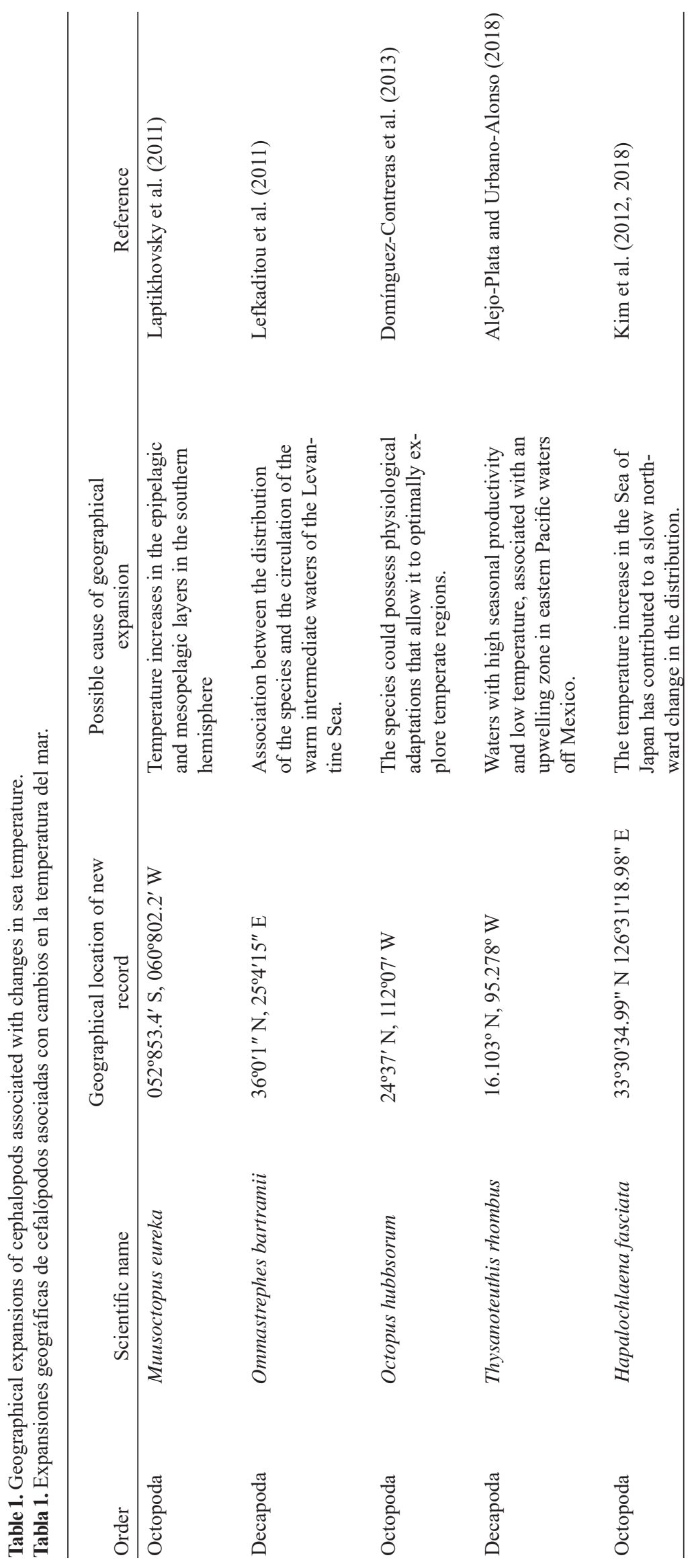


abundance, it had never been seen before. A combination of both hypotheses could be that $O$. briareus abundance is increasing and its distribution is expanding westward into the Gulf of Mexico because environmental conditions could now be favorable.

Octopus briareus is an organism that does not have larval stages and has accelerated growth rate, early sexual maturation, and a short life cycle (Robaina 1983). Furthermore, given its nocturnal habits, it is probably not a competing species for the Mexican four-eyed octopus, Octopus maya, an endemic species that is homogeneously distributed along the northern and western continental shelf of the Yucatán Peninsula, Mexico (Gamboa-Álvarez et al. 2015).

In addition to our record, octopi in the genus Tremoctopus, deep-water animals never before sighted by local people, have reportedly been caught recently by multiple artisanal fishermen in the northeastern Yucatán Peninsula. We therefore suggest that cephalopod biodiversity studies be conducted on the coasts of Yucatán and Campeche, Mexico, in order to update the lists of species inhabiting these areas. We also suggest sampling artisanal catches to assess whether these types of captures are incidental or indicate a change in species composition on the continental shelf of the Yucatán Peninsula.

\section{ACKNowledgments}

We are thankful for the financial support provided by Universidad Nacional Autonoma de Mexico (DGAPA-PAPIIT, IN223418). MAGA thanks the Mexican National Council for Science and Technology for the scholarship granted to carry out graduate studies.

\section{REFERENCES}

Alejo-Plata MC, Urbano-Alonso B. 2018. The finding of diamond squid Thysanoteuthis rhombus in the Gulf of Tehuantepec, Northeastern Tropical Pacific $=$ El hallazgo del calamar diamante Thysanoteuthis rhombus en el Golfo de Tehuantepec, Pacífico tropical noreste. Hidrobiológica. 28(1):147-150. https://doi.org/10.24275/uam/izt/dcbs/hidro/2018v28n1/alejo

Allcock L, Headlam J. 2018. Octopus briareus. The IUCN Red List of Threatened Species 2018: e.T163175A980439. Accessed 2019 Aug 26.

http://dx.doi.org/10.2305/IUCN.UK.2018-2.RLTS. T163175A980439.en

Aronson RB. 1986. Life history and den ecology of Octopus briareus Robson in a marine lake. J Exp Mar Biol Ecol. 95(1):37-56. https://doi.org/10.1016/0022-0981(86)90086-9

Bryant WR, Lugo J, Córdova C, Salvador A. 1991. Physiography and bathymetry. In: Salvador A (ed.), The Geology of North America. The Gulf of Mexico Basin. Vol. J, Boulder (CO): The Geological Society of America. p. 13-30. https://doi.org/10.1130/DNAG-GNA-J.13

Candela J, Tanahara S, Crepon M, Barnier B, Sheinbaum J. 2003. Yucatan Channel flow: observations versus CLIPPER ATL6 and MERCATOR PAM models. J Geophys Res. 108(C12):1-24. https://doi.org/10.1029/2003jc001961 sensible a los cambios ambientales, por lo que se considera un buen indicador de las circunstancias oceanográficas actuales (Puerta et al. 2015, Zaragoza et al. 2015). La segunda hipótesis es que la especie siempre ha habitado el área, pero debido a su baja abundancia, nunca se había visto. Una combinación de ambas hipótesis podría ser que debido a que las condiciones ambientales ahora podrían ser favorables para $O$. briareus, su abundancia está aumentando y su distribución se está expandiendo hacia el oeste en el golfo de México.

Octopus briareus es un organismo que no presenta estadios larvarios y tiene tasas de crecimiento aceleradas, maduración sexual temprana y ciclo de vida corto (Robaina 1983). Además, debido a sus hábitos nocturnos, probablemente no sea una especie competidora del pulpo mexicano de cuatro ojos, Octopus maya, una especie endémica que se distribuye de manera homogénea a lo largo de la región norte y oeste de la plataforma continental de la península de Yucatán, México (Gamboa-Álvarez et al. 2015).

Además de nuestro registro, hay informes de que varios pescadores artesanales del noreste de la península de Yucatán han capturado recientemente pulpos del género Tremoctopus, animales de aguas profundas nunca antes vistos por la población local. Por lo tanto, sugerimos que se realicen estudios de biodiversidad de cefalópodos en las costas de Yucatán y Campeche, México, para actualizar las listas de especies correspondientes a estas áreas. También sugerimos tomar muestras de las capturas de los pescadores artesanales para evaluar si este tipo de capturas son incidentales o si indican un cambio en la composición de especies de la plataforma continental de la península de Yucatán.

\section{Agradecimientos}

Agradecemos el apoyo financiero por parte de la Universidad Nacional Autónoma de México (UNAM) (DGAPA-PAPIIT, IN223418). MAGA agradece al Consejo Nacional de Ciencia y Tecnología de México por la beca otorgada para realizar estudios de posgrado.

Cervigón F, Cipriani R, Fischer W, Garibaldi L, Hendrickx M, Lemus AJ, Márquez R, Poutiers JM, Robaina G, Rodriquez B. 1992. Guía de campo de las especies comerciales marinas y de aguas salobres de la costa septentrional de Sur América [Field Guide to Commercial Marine and Brackish Water Species of the Northern Coast of South America]. Rome (Italy): Food and Agriculture Organization of the United Nations. p. 94-101.

Chollett I, Müller-Karger FE, Heron SF, Skirving W, Mumby PJ. 2012. Seasonal and spatial heterogeneity of recent sea surface temperature trends in the Caribbean Sea and southeast Gulf of Mexico. Mar Pollut Bull. 64(5):956-965. https://doi.org/10.1016/j.marpolbul.2012.02.016

Domínguez-Contreras JF, Ceballos-Vázquez BP, Hochberg FG, Arellano-Martínez M. 2013. A new record in a well-established population of Octopus hubbsorum (Cephalopoda: Octopodidae) expands its known geographic distribution range and maximum size. Am Malacol Bull. 31(1):95-99.

https://doi.org/10.4003/006.031.0122 
Ponce-Márquez et al.: Expansion of the geographical distribution of Octopus briareus

Foltz GR, Balaguru K, Hagos S. 2018. Interbasin differences in the relationship between SST and tropical cyclone intensification. Mont Weather Rev. 146(3):853-870. https://doi.org/10.1175/mwr-d-17-0155.1

Gamboa-Álvarez MÁ, López-Rocha JA, Poot-López GR. 2015. Spatial analysis of the abundance and catchability of the red octopus Octopus maya (Voss and Solís-Ramírez, 1966) on the continental shelf of the Yucatan Peninsula, Mexico. J Shellfish Res. 34(2):481-492. https://doi.org/10.2983/035.034.0232

Hanlon RT. 1983. Octopus briareus. In: Boyle PR (ed.), Cephalopod Life Cycles. London (UK): Academic Press. p. 251-266.

Hanlon RT, Messenger JB. 1996. Cephalopod behaviour. Cambridge (UK): Cambridge University Press. 232 p.

Jereb P, Roper CFE, Norman MD, Finn JK. 2014. Cephalopods of the world. An annotated and illustrated catalogue of cephalopod species known to date. Vol. 3, Octopods and Vampire Squids. FAO species catalogue for fishery purposes. No. 4, Vol. 3. Rome (Italy): Food and Agriculture Organization of the United Nations. 370 p.

Jury MR. 2011. Long-term variability and trends in the Caribbean Sea. Int J Oceanogr. 2011:465810. https://doi.org/10.1155/2011/465810

Jury MR. 2019. Factors underlying changes in salinity around the southeastern Antilles. J Mar Syst. 199:103208. https://doi.org/10.1016/j.jmarsys.2019.103208

Kaplan EH. 1999. A field guide to coral reefs: Caribbean and Florida. Boston: Houghton Mifflin Harcourt. 273 p.

Kaschner K, Kesner-Reyes K, Garilao C, Segschneider J, RiusBarile J, Rees T, Froese R. 2019. AquaMaps: Predicted range maps for aquatic species. [Place unknown]: AquaMaps; accessed 2020 May 30. https://www.aquamaps.org. Version $10 / 2019$.

Kim HS, Kwun HJ, Bae H, Park J. 2018. First reliable record of the blue-lined octopus, Hapalochlaena fasciata (Hoyle, 1886) (Cephalopoda: Octopodidae), from Jeju Island, Korea. J Asia Pac Biodivers. 11(1):21-24. https://doi.org/10.1016/j.japb.2018.01.005

Kim JH, Suzuki T, Shim KB, Oh EG. 2012. The widespread distribution of the venomous and poisonous blue-lined octopus Hapalochlaena spp., in the East/Japan Sea: Possible effects of sea warming. Fish Aquatic Sci. 15(1):1-8. https://doi.org/10.5657/fas.2012.0001

Laptikhovsky V, Arkhipkin A, Brickle P, Hearne S, Neely K. 2011. Species range shifts due to environmental changes in scaled squid, Pholidoteuthis massyae and bathyal octopus, Muusoctopus eureka. Mar Biodivers Rec. 4:e34. https://doi.org/10.1017/S1755267210001053

Lefkaditou E, Peristeraki P, Chartosia N, Salman A. 2011. Recent findings of Ommastrephes bartramii (Cephalopoda: Ommastrephidae) in the eastern Mediterranean and the implication on its range expansion. Mediterr Mar Sci. 12(2):413428.

https://doi.org/10.12681/mms.41

Lluch-Cota SE, Tripp-Valdez M, Lluch-Cota DB, Lluch-Belda D, Verbesselt J, Herrera-Cervantes H, Bautista-Romero JJ. 2013. Recent trends in sea surface temperature off Mexico. Atmósfera. 26(4):537-546. https://doi.org/10.1016/s0187-6236(13)71094-4

Muller-Karger FE, Smith JP, Werner S, Chen R, Roffer M, Liu Y, Muhling B, Lindo-Atichati D, Lamkin J, Cerdeira-Estrada S, et al. 2015. Natural variability of surface oceanographic conditions in the offshore Gulf of Mexico. Prog Oceanogr. 134:54-76. https://doi.org/10.1016/j.pocean.2014.12.007

Nurse LA, Charlery JL. 2016. Projected SST trends across the Caribbean Sea based on PRECIS downscaling of ECHAM4, under the SRES A2 and B2 scenarios. Theor Appl Climatol. 123(1-2):199-215. https://doi.org/10.1007/s00704-014-1346-1

Philippart CJM, van Aken HM, Beukema JJ, Bos OG, Cadée GC, Dekker R. 2003. Climate-related changes in recruitment of the bivalve Macoma balthica. Limnol Oceanogr. 48(6):2171-2185. https://doi.org/10.4319/lo.2003.48.6.2171

Pickford GE. 1945. Le poulpe Américain: A study of the littoral Octopoda of the Western Atlantic. Trans Conn Acad Arts Sci. 36:701-811.

Poloczanska ES, Burrows MT, Brown CJ, García-Molinos J, Halpern BS, Hoegh-Guldberg O, Kappel CV, Moore PJ, Richardson AJ, Schoeman DS, et al. 2016. Responses of marine organisms to climate change across oceans. Front Mar Sci. 3:62.

https://doi.org/10.3389/fmars.2016.00062

Puerta P, Hunsicker ME, Quetglas A, Álvarez-Berastegui D, Esteban A, González M, Hidalgo M. 2015. Spatially explicit modeling reveals cephalopod distributions match contrasting trophic pathways in the western Mediterranean Sea. PLOS ONE. 10(7):e0133439. https://doi.org/10.1371/journal.pone.0133439

Robaina GO. 1983. Sobre el cultivo y mantenimiento de Octopus briareus Robson 1929 (Cephalopoda: Octopoda). [On the cultivation and maintenance of Octopus briareus Robson 1929 (Cephalopoda: Octopoda)]. Isla de Margarita (Venezuela): Centro de Investigaciones Científicas de la Universidad de Oriente. 20 p.

Robson GC. 1929a. A Monograph of the Recent Cephalopoda based on the collections in the British Museum (Natural History). Part I Octopodinae. London (UK): British Museum (Nat. Hist.). https://doi.org/10.5962/bhl.title.106032

Robson GC. 1929b. Notes on the Cephalopoda. IX: Remarks on Atlantic Octopoda andc. in the Zoölogische Museum, Amsterdam. Ann Mag Nat Hist Series 10. 3(18):609-618. https://doi.org/10.1080/00222932908673018

Salvador A. 1991. Origin and development of the Gulf of Mexico Basin. In: Salvador A (ed.), The Geology of North America. The Gulf of Mexico basin Vol. J. Boulder (CO): The Geological Society of America. p. 389-444. https://doi.org/10.1130/DNAG-GNA-J.389

Schmitz WJ Jr., Biggs DC, Lugo-Fernández A, Oey LY, Sturges W. 2005. A synopsis of the circulation in the Gulf of Mexico and on its Continental Margins. In: Sturges W, Lugo-Fernandez A (eds.), Circulation in the Gulf of Mexico: Observations and Models. Geophysical Monograph Ser. Vol. 161. Florida (USA):AGU Books. p. 11-31. https://doi.org/10.1029/161GM03

Sheppard C, Rioja-Nieto R. 2005. Sea surface temperature 18712099 in 38 cells in the Caribbean region. Mar Environ Res. 60(3):389-396. https://doi.org/10.1016/j.marenvres.2004.12.006

Smith RH, Johns EM, Goni GJ, Trinanes J, Lumpkin R, Wood AM, Kelble CR, Cummings SR, Lamkin JT, Privoznik S. 2014. Oceanographic conditions in the Gulf of Mexico in July 2010, during the Deepwater Horizon oil spill. Cont Shelf Res. 77(1):118-131. https://doi.org/10.1016/j.csr.2013.12.009

Snyderman M, Wiseman C. 1996. Guide to marine life: Caribbean, Bahamas, Florida. New York: Aqua Quest Publications Inc. $284 \mathrm{p}$.

Varela R, Lima FP, Seabra R, Meneghesso C, Gómez-Gesteira M. 2018. Coastal warming and wind-driven upwelling: A global analysis. Sci Total Environ. 639:1501-1511. https://doi.org/10.1016/j.scitotenv.2018.05.273 
Vidal VMV, Vidal FV, Hernández OAF. 1991. Atlas Oceanográfico del Golfo de México. Vol3, Circulación y transportes baroclínicos, hidrografía, distribución de masas de agua y propiedades cinemáticas de pares ciclones-anticiclones durante octubre de 1986. Cuernavaca (Morelos, México): Instituto de Investigaciones Eléctricas, Grupo de Estudios Oceanográficos. 586 p.

Voss NA, Vecchione M, Toll RB, Sweeney MJ. 1998. Systematics and Biogeography of Cephalopods. Vol. II. Smithsonian Contributions to Zoology. 586:277-599. https://doi.org/10.5479/si.00810282.586.277
Weishampel JF, Bagley DA, Ehrhart LM. 2004. Earlier nesting by loggerhead sea turtles following sea surface warming. Glob Chang Biol. 10(8):1424-1427. https://doi.org/10.1111/j.1529-8817.2003.00817.x

Zaragoza N, Quetglas A, Hidalgo M, Álvarez-Berastegui D, Balbín R, Alemany F. 2015. Effects of contrasting oceanographic conditions on the spatiotemporal distribution of Mediterranean cephalopod paralarvae. Hydrobiologia. 749(1):1-14.

https://doi.org/10.1007/s10750-014-2132-x

Received March 2020, accepted June 2020. 